\title{
PENGEMBANGAN PERANGKAT PEMBELAJARAN IPA MODEL INKUIRI TERBIMBING UNTUK MELATIHKAN KETERAMPILAN PROSES SAINS SISWA SMP
}

\author{
Riris Susanti' ${ }^{1)}$ Z. A. Imam Supardi' ${ }^{2)}$, Sifak Indana ${ }^{3)}$ \\ ${ }^{1)}$ Mahasiswa Program Studi Pendidikan Sains, Program Pascasarjana Universitas Negeri Surabaya \\ 2), 3)Dosen Pascasarjana Prodi Pendidikan Sains Universitas Negeri Surabaya \\ E-mail: ririssusanti45@yahoo.co.id
}

\begin{abstract}
Abstrak: Penelitian ini bertujuan untuk menghasilkan perangkat pembelajaran IPA model inkuiri terbimbing yang layak untuk melatihkan keterampilan proses sains siswa SMP. Penelitian ini merupakan penelitian pengembangan dengan model Dick-Carey dan desain uji coba penelitian menggunakan one group pre-test post-test design. Subyek penelitian adalah perangkat pembelajaran yang terdiri dari silabus, RPP, LKS, Buku Ajar Siswa, Instrumen Penilaian Keterampilan Proses Sains. Uji coba dilaksanakan pada siswa kelas VIII SMP sebanyak 28 siswa. Metode pengumpulan data menggunakan validasi, observasi, tes, dan pengisian angket. Teknik analisis data menggunakan deskriptif kuantitatif dan kualitatif. Hasil analisis data penelitian menunjukkan bahwa: (1) perangkat yang dikembangkan valid; (2) pembelajaran terlaksana dengan kategori baik; (3) siswa menjadi aktif dalam pembelajaran (4) keterampilan proses sains menunjukkan kategori tinggi (5) siswa memberikan respon positif dengan kategori sangat baik terhadap pembelajaran. Berdasarkan hasil penelitian di atas, dapat disimpulkan bahwa perangkat pembelajaran IPA model inkuiri terbimbing yang telah dikembangkan layak untuk melatihkan keterampilan proses sains siswa.
\end{abstract}

Kata kunci: Model Inkuiri Terbimbing, Keterampilan Proses Sains

\begin{abstract}
This research aimed to produce science learning materials that are feasible to fascilitate student's science process skill of junior high school. This research was conducted to implement the teaching and learning materials based on guided inquiry model. This research developed them using Dick-Carey's model and try outed using one group pre-test post-test design. The subjects of this research was science learning materials that consist of syllabus, lesson plan, student's work sheet, instructional media, evaluation sheet to measure student's science process skill. It was conducted to 28 eighth grade students in junior high school. The data were collected using validation, observation, test, and questionnaire. The data were analyzed using descriptive quantitative and qualitative technique. The results showed: (1) the teaching and learning materials developed are valid; (2) learning implementation got a good category; (3) the student's participation in actively learning; (4) student's science process skill showed high category, (5) the students give positive response with very good category toward teaching and learning process. Based on this results, it can be concluded that the set of learning materials based on guided inquiry model have been developed are feasible to fascilitate the student's science process skill.
\end{abstract}

Keywords: Model Inkuiri Terbimbing, Keterampilan Proses Sains

\section{PENDAHULUAN}

Kurikulum 2013 mengamanatkan dua pendekatan yaitu pendekatan saintifik (scientific approach) dan pendekatan keterampilan proses agar diterapkan dalam pembelajaran sains di sekolah yang bertujuan untuk mencapai visi Kurikulum 2013. Pendekatan saintifik memberikan pengalaman belajar siswa untuk melakukan kegiatan mengamati, bertanya, mengumpulkan informasi, menalar, dan mengkomunikasikan terkait materi pembelajaran. Namun Wasis (2015, p. 17) memberikan tuntutan pengalaman belajar lebih tinggi kepada siswa dengan menyatakan bahwa pembelajaran sains justru seharusnya melatihkan tidak cukup hanya 5M, melainkan mencakup berbagai keterampilan yang disebut keterampilan proses sains.
Keterampilan proses sains didefinisikan oleh Sheeba (2013, p. 1) sebagai intellectual skills needed for scientific investigation attained by students as a result of learning scinece. Sedangkan Ozgelen (2012, p. 285) memberikan definisi sedikit berbeda yaitu Science Process Skill encompasses the mental and physical skills for collecting and organizing information and then using it to make predictions, explain fenomena, and solve problems. Science -A Process Approach (SAPA) mengelompokkan keterampilan tersebut menjadi keterampilan proses dasar (basic skills) dan keterampilan proses terintegrasi (integrated skills). Keterampilan proses dasar terdiri dari mengamati, menginferensi, mengukur, mengklasifikasi, memprediksi, dan mengkomunikasikan sedangkan keterampilan proses sains lanjut/terpadu terdiri dari 
merumuskan hipotesis, mendefinisikan secara operasional, mengontrol variabel, merancang dan melakukan eksperimen, menganalisis data, dan merumuskan model (Padilla, 1990, p. 1).

Pentingnya melatihkan keterampilan proses sains kepada siswa dalam pembelajaran sains karena keterampilan proses sains tidak hanya sesuai dengan karakteristik sains "a systematic and structured knowledge on a regular basis, generally accepted (universal) and a collection of data from observation and experiments"(Sukarno dkk, 2013, p 79) tetapi keterampilan ini juga memudahkan individu untuk dapat menyelesaikan permasalahan sehari-hari. Hal ini sesuai dengan pernyataan Kazeni yang dikutip Aydogdu dkk. (2014, p. 1) "the development at science process skills enables students to gain the skills necessary to solve everyday problems". Manfaat lain dari keterampilan ini juga dikemukakan oleh Semiawan (dalam Susanti, 2005, p. 24) "dengan mengembangkan keterampilan-keterampilan memproseskan perolehan, anak akan mampu menumbuhkan dan mengembangkan sendiri fakta dan konsep serta penumbuhan dan pengembangan sikap dan nilai yang dituntut". Oleh karena itu, pembelajaran sains diharapkan menekankan keterampilan proses sains yang tidak hanya mengantarkan siswa terhadap penguasaan materi pelajaran, tetapi juga memberikan keleluasaan siswa untuk mengembangkan keterampilan fisik maupun mental, sehingga pembelajaran menjadi bermakna dan relevan bagi siswa. Pada akhirnya terbentuk sikap yang sesuai dengan tuntutan kehidupan siswa dan mampu menginternalisasikan nilai yang diperoleh untuk diri sendiri dan lingkungan sekitarnya dalam kehidupan sehari-hari.

Kenyataan di lapangan mengindikasikan bahwa hasil belajar sains siswa Indonesia tergolong rendah. Hasil tersebut mengacu pada studi internasional TIMSS (Trends in International Mathematics and Science Study) yang menunjukkan kemampuan rata-rata TIMSS tahun 2003, 2007, dan 2011 secara berurutan adalah 435, 420, dan 406. Siswa Indonesia hanya 3\% yang menjadi responden studi TIMSS mencapai high level, $0 \%$ mencapai advanced level, 54\% mencapai kemampuan sains rendah (low level). Capaian tersebut menunjukkan rata-rata siswa Indonesia hanya mampu mengenali sejumlah fakta dasar tetapi belum mampu mengkomunikasikan berbagai topik sains. Hal yang sama juga pada tahun 2007 dari studi TIMSS menunjukkan kemampuan rata-rata siswa Indonesia merespon soal format uraian lebih rendah (kurang dari $35 \%$ ) dibandingkan kemampuan rata-ratanya dalam merespon soal format pilihan (sekitar 45\%) (Wasis, 2015, p. 8). Analisis soal-soal TIMSS 2007 dan 2011 dikemukakan oleh Bayraktar (dalam Aydogdu dkk, 2014, p. 3) menunjukkan bahwa persoalan yang diujikan pada TIMSS cenderung mengevalusi keterampilan berargumen, pemecahan masalah, melakukan analisis dan sintesis, merumuskan hipotesis, membuat prediksi, merancang eksperimen, generalisasi, dan evaluasi prosedur eksperimen. Dengan kata lain rendahnya hasil sains TIMSS menunjukkan bahwa keterampilan proses sains siswa Indonesia juga rendah.

Rendahnya keterampilan proses sains siswa SMP juga ditunjukkan oleh survey yang dilakukan oleh Sukarno dkk. tentang keterampilan proses sains (2013, p. 81 ) terhadap 322 responden siswa kelas VIII SMP yang bertujuan mengelompokkan level keterampilan proses sains. Penelitian tersebut menunjukkan bahwa 43,48\% siswa tergolong kategori rendah, 30,43\% siswa tergolong menengah, dan $26,09 \%$ siswa tergolong kategori tinggi. Rendahnya hasil tersebut juga disimpulkan bahwa salah satu penyebabnya adalah pembelajaran sains yang dilakukan oleh guru cenderung tradisional sehingga kurang mengeksplor keterampilan proses sains (Sukarno dkk, 2013, p. 82).

Berdasarkan observasi dan wawancara yang dilakukan di SMP Negeri 2 Kesamben, pembelajaran IPA kurang dapat mengembangkan keterampilan proses sains siswa, hal ini ditunjukkan oleh aktivitas siswa yang hanya duduk mendengarkan guru, mencatat, dan mengerjakan soal latihan. Siswa memperoleh pengetahuan hanya dari membaca atau mendengarkan guru saja, sehingga siswa menjadi pasif dan pengetahuan yang diperoleh hanya sebatas apa yang ada dalam buku teks atau hanya informasi yang diperoleh dari guru saja. Pembelajaran juga jarang dilakukan kegiatan praktikum yang berdasarkan pada aktivitas siswa, sehingga keterampilan proses sains siswa seperti merumuskan masalah, menentukan variabel, merumuskan hipotesis, membuat dan menganalisis tabel data, dan merumuskan kesimpulan tidak berkembang.

Hasil nilai UN siswa SMP Negeri 2 Kesamben termasuk rendah. Hal ini didasarkan data hasil Ujian Nasional Kementerian Pendidikan dan Kebudayaan tahun 2015 menunjukkan nilai rata-rata materi getaran dan gelombang 44,26. Sedangkan rata-rata nilai UN materi getaran gelombang di tingkat Kabupaten sebesar 56,12. Data tersebut menunjukkan rata-rata nilai UN jauh berada di bawah rata-rata jika dibandingkan dengan sekolah lainnya. Kemampuan siswa dalam menyelesaikan persoalan Ulangan Harian untuk materi getaran, gelombang, dan bunyi tahun pelajaran 2014/2015 juga rendah, banyak siswa mendapat nilai di bawah KKM, hanya $20 \%$ siswa yang mencapai nilai di atas KKM yang ditetapkan sekolah yaitu 73 .

Oleh karena itu, pembelajaran sains tidak sekedar memperoleh pengetahuan yang didapatkan dari aktivitas mendengarkan informasi, kemudian disimpan dalam memori di otak dalam jangka waktu tertentu. 
Pembelajaran sains seharusnya menekankan pada pemberian pengalaman belajar secara langsung melalui penggunaan dan pengembangan keterampilan proses dan sikap ilmiah. Sesuai dengan tuntutan Kurikulum 2013 bahwa pembelajaran IPA sebaiknya dilaksanakan secara inkuiri (scientific inquiry) untuk menumbuhkan kemampuan berpikir, bekerja, dan bersikap ilmiah serta mengomunikasikannya sebagai aspek penting kecakapan hidup (Lampiran III Permendikbud, 2014, p. 433).

Pembelajaran model inkuiri terbimbing memberikan kesempatan seluas-luasnya bagi siswa untuk aktif menyelidiki suatu permasalahan dari suatu fenomena/gejala alam sampai menjadikan hasil penyelidikannya suatu kesimpulan. Tidak hanya itu dalam proses penyelidikan yang dilakukan siswa, model tersebut juga menumbuhkan kemampuan menganalisis data dan informasi, seperti pernyataan dari Chin \& Kayalvizhi inquiry science teaching engages students in thinking skills and processes, ie formulating questions and hypotheses, predicting, interpreting data, synthesizing information and making conclusion (dalam Duran, 2014, p. 4511 ) dan Handayanto (2003, p. 72) bahwa model inkuiri terbimbing merupakan model pembelajaran yang melatih siswa untuk belajar menemukan masalah, mengumpulkan, mengorganisasi dan memanipulasi data, serta memecahkan masalah.

Sejalan dengan hal tersebut, hasil penelitian yang dilakukan oleh Nworgu dan Otum (2013, p. 35) menunjukkan bahwa pembelajaran inkuiri terbimbing dapat meningkatkan keterampilan proses sains, penelitian tersebut juga didukung oleh hasil studi yang dilakukan oleh Rizal (2014, p. 159) yang menyimpulkan bahwa keterampilan proses sains dan penguasaan konsep IPA siswa terhadap sains dapat diperbaiki dengan pembelajaran inkuiri terbimbing.

Berdasarkan uraian di atas, maka dilakukan penelitian dengan judul "Pengembangan Perangkat Pembelajaran IPA Model Inkuiri Terbimbing untuk Melatihkan Keterampilan Proses Sains Siswa SMP.

\section{METODE PENELITIAN}

Penelitian ini termasuk penelitian pengembangan perangkat yang mengacu pada model Dick and Carey yang diadaptasi sesuai dengan kebutuhan penelitian. Adaptasi langkah-langkah pengembangan tersebut dijabarkan sebagai berikut:

1) Identifikasi tujuan pengajaran secara umum

2) Analisis materi pembelajaran

3) Analisis siswa

4) Perumusan tujuan pembelajaran

5) Penyusunan tes

6) Memilih strategi pembelajaran

7) Menyusun perangkat pembelajaran
8) Validasi perangkat dan

9) Tahap Uji Coba.

Tahap Uji coba perangkat pembelajaran yang dikembangkan dalam penelitian ini menggunakan rancangan One Group Pretest-Postest Design dengan rumusan desain sebagai berikut:

\section{$\begin{array}{lll}\mathbf{O}_{1} & \mathbf{x} & \mathbf{O}_{2}\end{array}$}

(Fraenkel, Wallen \& Hyun, 2012, p. 269)

Keterangan:

$\mathrm{O}_{1}=\mathrm{Uji}$ awal (pre test), untuk mengukur kemampuan awal siswa sebelum diberikan perlakuan yang meliputi kemampuan keterampilan proses sains.

$\mathrm{X}=$ Perlakuan (treatment), dengan menggunakan model inkuiri terbimbing

$\mathrm{O}_{2}=\quad \mathrm{Uji}$ akhir (post test), untuk mengukur kemampuan aspek keterampilan proses sains siswa setelah diberikan perlakuan.

Variabel penelitian ini meliputi validitas perangkat pembelajaran, variabel yang terkait kepraktisan perangkat yang meliputi: keterlaksanaan pembelajaran, aktivitas siswa, dan variabel yang terkait keefektifan perangkat pembelajaran yang meliputi: keterampilan proses sains siswa.

Subyek penelitian berupa perangkat pembelajaran yang dikembangkan terdiri dari: silabus, rencana pelaksanaan pembelajaran (RPP), lembar kerja siswa (LKS), buku ajar siswa (BAS), penilaian keterampilan proses sains yang diujicobakan pada siswa kelas VIII SMP Negeri 2 Kesamben dari tanggal 18-29 Juli pada semester ganjil tahun pelajaran 2016-2017.

Metode yang digunakan untuk mengumpulkan data yaitu validasi, observasi, tes, dan angket. Teknik analisis data yang digunakan meliputi.

\section{A. Analisis validasi perangkat pembelajaran}

Analisis validasi perangkat pembelajaran dilakukan dengan cara menghitung rata-rata tiap komponen yang kemudian dikategorikan berdasarkan pada Tabel 1 berikut ini.

Tabel 1. Deskripsi Skor Validasi Perangkat

\begin{tabular}{|l|l|l|}
\hline $\begin{array}{l}\text { Interval Skor } \\
\text { Rata-Rata }\end{array}$ & Kategori & Keterangan \\
\hline $\begin{array}{l}1,00 \leq \mathrm{SV} \leq \\
1,59\end{array}$ & $\begin{array}{l}\text { Tidak } \\
\text { Valid }\end{array}$ & $\begin{array}{l}\text { Belum dapat digunakan } \\
\text { dan masih } \\
\text { memerlukan konsultasi }\end{array}$ \\
\hline $\begin{array}{l}1,60 \leq \mathrm{SV} \leq \\
2,59\end{array}$ & $\begin{array}{l}\text { Kurang } \\
\text { Valid }\end{array}$ & $\begin{array}{l}\text { Dapat digunakan } \\
\text { dengan banyak revisi }\end{array}$ \\
\hline $\begin{array}{l}2,60 \leq \mathrm{SV} \leq \\
3,59\end{array}$ & Valid & $\begin{array}{l}\text { Dapat digunakan } \\
\text { dengan sedikit revisi }\end{array}$ \\
\hline $\begin{array}{l}3,60 \leq \mathrm{SV} \leq \\
4,00\end{array}$ & $\begin{array}{l}\text { Sangat } \\
\text { Valid }\end{array}$ & $\begin{array}{l}\text { Dapat digunakan tanpa } \\
\text { revisi }\end{array}$ \\
\hline
\end{tabular}

(Adaptasi Ratumanan dan Laurens, 2011, p. 34) 


\section{B. Analisis keterlaksanaan rencana pelaksanaan pembelajaran \\ Penilaian dilakukan pengamat terhadap} keterlaksanaan tahap pendahuluan, kegiatan inti, penutup, pengelolaan waktu, dan pengamatan suasana kelas kemudian dideskripsikan berdasarkan kriteria berikut ini.

Tabel 2. Kriteria Keterlaksanaan Pembelajaran

\begin{tabular}{|l|l|}
\hline Skor & Kriteria \\
\hline $0,00-1,49$ & Kurang \\
\hline $1,50-2,59$ & Cukup \\
\hline $2,60-3,49$ & Baik \\
\hline $3,50-4,00$ & Baik Sekali \\
\hline
\end{tabular}

\section{Analisis aktivitas siswa}

Data hasil pengamatan aktivitas siswa selama kegiatan pembelajaran dianalisis deskriptif kuantitatif dengan menggunakan rumus (Arifin, 2010a, p. 272), yaitu :

$$
\mathrm{P}=\frac{\sum \mathbf{R}}{\sum \mathrm{N}} \times 100 \%
$$

Keterangan:

$\mathrm{P} \quad=$ Persentase aktivitas siswa

$\sum \mathrm{R}=$ Jumlah frekuensi tiap aktivitas yang muncul

$\sum \mathrm{N}=$ Jumlah total frekuensi aktivitas

\section{Analisis keterampilan proses sains}

Analisis ketuntasan indikator dihitung berdasarkan persentase siswa yang mencapai indikator tersebut. Indikator dinyatakan tuntas jika persentase siswa yang mencapai indikator tersebut $\geq 75 \%$. Persentase ketuntasan indikator dihitung menggunakan rumus sebagai berikut (BSNP, 2006):

Persentase Ketuntasan

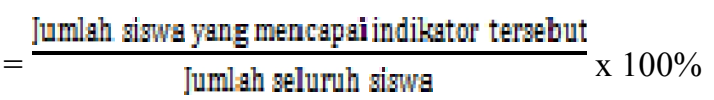

Ketuntasan siswa untuk setiap indikator keterampilan proses sains diukur berdasarkan pencapaian skor $\geq 3$, kemudian perolehan total keterampilan proses sains siswa dikategorikan berdasarkan kriteria berikut.

Tabel 3. Kategori Rentang Skor Keterampilan Proses Sains

\begin{tabular}{|l|l|l|}
\hline No & Rentang Skor & Kategori \\
\hline 1. & $16-20$ & Tinggi \\
\hline 2. & $8-15$ & Sedang \\
\hline 3. & $0-7$ & Rendah \\
\hline
\end{tabular}

(Sukarno dkk. 2013, p. 80)

Data yang diperoleh dari pengkategorian kemampuan keterampilan proses sains siswa kemudian dihitung secara persentase yang meliputi tinggi, sedang, dan tinggi (Sukarno dkk. 2013, p. 80).

$$
\mathrm{P}=\frac{x}{n} \times 100 \%
$$

Keterangan:

$\mathrm{P}=$ Persentase kemampuan keterampilan proses sains

$x=$ Jumlah siswa dalam setiap kategori

$n=$ Jumlah siswa keseluruhan

Keterampilan proses sains yang diperoleh dari metode penilaian kinerja meliputi penilaian melakukan percobaan, mengkomunikasikan (penyusunan laporan dan presentasi). Skor tiap aspek kemudian dijumlah dan hasilnya dikonversi ke dalam predikat dan deskripsi. Nilai siswa aspek keterampilan konkrit dinyatakan dalam skala 0-100 dan predikatnya ditentukan sebagai berikut (Permendikbud No 53, 2015, p.43):

$\begin{array}{ll}\text { Sangat baik (A) } & : 86-100 \\ \text { Baik (B) } & : 71-85 \\ \text { Cukup (C) } & : 56-70 \\ \text { Kurang (D) } & : \leq 55\end{array}$

\section{HASIL PENELITIAN DAN DISKUSI}

A. Validitas Perangkat Pembelajaran

Hasil validasi perangkat ditunjukkan Gambar 1 berikut

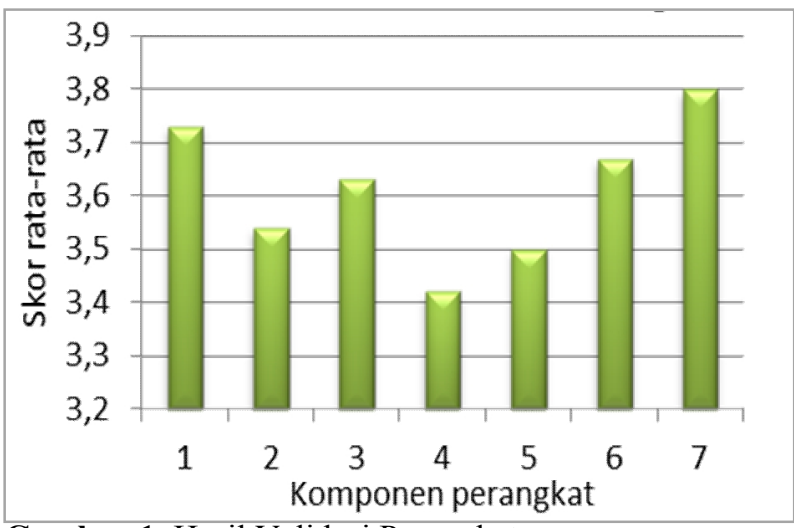

Gambar 1. Hasil Validasi Perangkat

Keterangan:
$1:$ Silabus
2 : Rencana Pelaksanaan Pembelajaran
3 : Lembar Kerja Siswa (LKS)
4 : BAS (Buku Ajar Siswa)
5: Keterampilan Proses Sains
6. Keterampilan melakukan percobaan
7. Keterampilan mengkomunikasikan

Validasi silabus dilakukan untuk mengetahui sistematika komponen silabus dan keterkaitan konten yang ada dalam silabus yang berdasarkan pada prinsipprinsip silabus. Hasil validasi silabus menunjukkan bahwa pengembangan silabus dari segi komponen sudah memenuhi kriteria sistematika yang ditetapkan (Lampiran III Permendikbud, 2014, p. 445), silabus disusun dalam format dan sistematika yang jelas, sehingga dapat diterapkan dalam pembelajaran.

Penyusunan silabus juga memperhatikan kesesuaian antara kegiatan pembelajaran dengan indikator pencapaian kompetensi, langkah-langkah kegiatan 1258 
inkuiri dan pendekatan scientific yang disarankan dalam Kurikulum 2013. Penyusunan silabus juga memenuhi prinsip menyeluruh yang ditunjukkan dengan pengembangan indikator pencapaian kompetensi yang menyangkut tiga aspek ranah yaitu kognitif, afektif, dan psikomotorik. Dengan demikian aspek validasi yang mencakup identitas, kegiatan pembelajaran, alokasi waktu, pemilihan alat dan bahan, serta penilaian (evaluasi) dalam silabus sangat valid dan layak untuk diterapkan dalam kegiatan pembelajaran.

RPP yang dikembangkan termasuk kategori layak atau sangat valid, karena penyusunan RPP berdasarkan pada format Kurikulum 2013 dan memuat beberapa komponen RPP yang mengacu Permendikbud No. 58 Tahun 2014. Kegiatan pembelajaran yang terdapat dalam RPP disesuaikan dengan fase-fase model inkuiri terbimbing yang dipadukan dengan pendekatan scientific. Perpaduan ini diharapkan dapat menjadi pembelajaran yang dapat mengintegrasikan sikap, pengetahuan, dan keterampilan sehingga dapat membekali siswa dengan kompetensi IPA yang utuh. RPP yang dikembangkan juga menyertakan kegiatan pembelajaran yang berpotensi dapat melatihkan keterampilan proses sains siswa yang didasarkan analisis K.D. 4.10 menyajikan hasil penyelidikan tentang getaran, gelombang, dan bunyi. Penjabaran jenis penilaian juga tercantum dalam RPP yang didasarkan pada indikator pencapaian kompetensi yang meliputi teknik penilaian, jenis penilaian, dan rubrik penilaian

Hasil validasi menunjukkan bahwa Buku Ajar Siswa yang disusun dikategorikan layak karena telah disesuaikan dengan panduan penyusunan bahan ajar oleh Depdiknas (2004) yang dikutip oleh Prastowo (2012, p. 73) yaitu 1) judul yang harus disesuaikan dengan kompetensi dasar, 2) susunan tampilannya jelas dan menarik, 3) bahasa yang mudah, 4) adanya stimulan, 5) kemudahan dibaca, 6) materi intruksional.

Penyusunan buku ajar siswa didasarkan pada analisis Kompetensi Dasar yang terdapat pada standar isi Kurikulum 2013. Secara substansial, buku ajar siswa disusun juga untuk mengembangkan aspek pengetahuan, keterampilan, dan sikap (nilai) bagi siswa. Hal ini ditunjukkan adanya materi-materi yang berisi konsep, prinsip, dan hukum dalam bahan ajar. Keterampilan yang dilatihkan pada buku ajar terkait keterampilan dalam berinkuiri dan aspek sikap diwujudkan dalam bentuk refleksi diri siswa terhadap keterkaitan materi sebagai ciptaan Tuhan Yang Maha Esa.

Penyusunan buku ajar mempertimbangkan dimensi pengetahuan yang relevan dalam kehidupan seharihari, di samping itu informasi berkaitan dengan perkembangan ilmu pengetahuan dan teknologi terbaru mengenai materi getaran, gelombang, dan bunyi.
Penyajian buku ajar dikemas dalam bentuk yang menarik dengan tampilan ilustrasi dan gambar, cetakan huruf yang berwarna. Sejumlah pembahasan tentang konsep-konsep IPA disusun dalam dialog interaktif antara guru dan siswa juga dimasukkan dalam buku ajar siswa yang bertujuan untuk membangkitkan motivasi dan keaktifan siswa dalam kegiatan pembelajaran.

Soal tes keterampilan proses sains disusun berdasarkan indikator keterampilan proses sains yaitu memprediksi ( memprediksi dengan ekstrapolasi data), merumuskan hipotesis (membangun sebuah hipotesis ketika diberi satu masalah atau pertanyaan), interpretasi data (membangun interpretasi yang sahih dari data), mengidentifikasi dan mengontrol variabel, merumuskan kesimpulan yang sahih.

Hasil validasi terhadap instrumen tes keterampilan proses sains menunjukkan bahwa 5 unit soal keterampilan proses sains dikategorikan valid. Dengan demikian, dapat disimpulkan bahwa tes yang dikembangkan layak untuk diujikan kepada siswa setelah melalui revisi kecil sesuai dengan saran validator. Saran dari validator untuk perbaikan terdapat pada butir tes memprediksi pada indikator ekstrapolasi data dalam bentuk pola. Untuk melatihkan indikator ini siswa tidak harus dilatihkan menyusun grafik tetapi pembuatan tabel data juga bisa digunakan untuk melatihkan indikator keterampilan memprediksi.

Instrumen penilaian kinerja keterampilan proses sains penelitian ini berdasarkan analisis KD 4.10 Menyajikan hasil penyelidikan tentang getaran, gelombang, dan bunyi. Instrumen yang dikembangkan meliputi instrumen keterampilan melakukan percobaan, keterampilan komunikasi (keterampilan menyusun laporan, dan keterampilan presentasi)

Hasil validasi instrumen keterampilan melakukan percobaan dikategorikan valid. Hasil validasi instrumen penyusunan laporan (rumusan masalah, hipotesis, hasil, kelengkapan dan kerapian) termasuk kategori sangat valid. Aspek penilaian penyusunan laporan lainnya (alat, bahan dan prosedur serta kesimpulan) dengan kategori valid dan instrumen penilaian keterampilan menyajikan laporan secara lisan diperoleh kategori sangat valid. Dengan demikian instrumen penilaian kinerja keterampilan proses sains secara umum termasuk layak untuk diterapkan dalam pembelajaran. Hasil validasi tersebut menunjukkan bahwa penyusunan instrumen keterampilan tersebut berdasarkan PP No. 53 tahun 2015. Penyusunan instrumen dilengkapi dengan rubrik penilaian sebagai pedoman guru dalam melakukan penilaian terhadap produk laporan maupun kinerja melakukan percobaan dan presentasi siswa. Petunjuk laporan juga diinformasikan ke siswa sebagai arahan dan panduan siswa dalam penyusunan laporan. 


\section{B. Kepraktisan Perangkat Pembelajaran \\ 1. Keterlaksanaan RPP \\ Data hasil pengamatan keterlaksanaan RPP ditunjukkan pada Gambar 2 berikut ini.

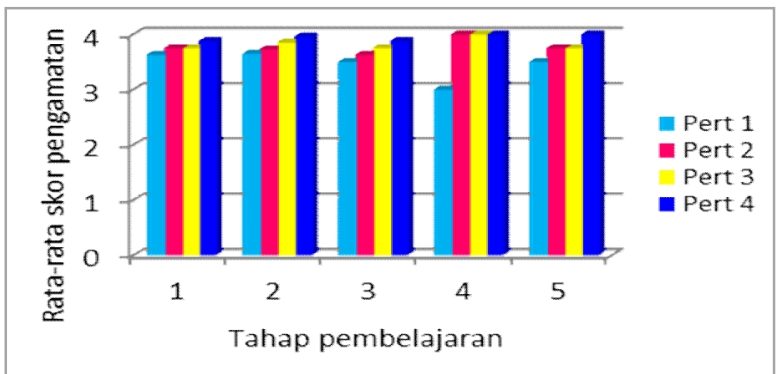

Gambar 2. Keterlaksanaan RPP

Keterangan:
1 : Pendahuluan
2: Kegiatan inti
4 : Pengelolaan waktu
3 : Kegiatan penutup
5 : Suasana kelas

Pada tahap Pendahuluan, skor rata-rata keterlaksanaan diperoleh sebesar 3,75 dengan kategori baik. Pada kegiatan ini, guru menciptakan suasana untuk mempersiapkan siswa terhadap pembelajaran secara mental dan membangkitkan atensi siswa agar terpusat pada materi yang akan dipelajari. Pada tahap ini guru mengajukan masalah dengan menyajikan fenomena awal. Kegiatan tersebut masuk dalam fase identifikasi dan penetapan ruang lingkup masalah yang menekankan kegiatan motivasi untuk menarik perhatian dan antusiasme siswa terhadap pembelajaran. Pengajuan masalah yang menantang dan relevan dalam kehidupan sehari-hari akan membangkitkan motivasi bagi siswa untuk mengikuti pembelajaran sebagaimana pernyataan Kulthau et.al (2007, p. 30) when the learning is driven by student's own questions and connects to their own of the world, motivation is natural and intrinsic.

Tahap kedua pembelajaran yaitu kegiatan inti. Empat fase inkuiri terbimbing berada pada tahap kegiatan ini. Rata-rata skor pada kegiatan inti sebesar 3,80 yang termasuk dalam kategori baik. Fase-fase inkuiri merencanakan dan memprediksi hasil, penyelidikan untuk pengumpulan data, interpretasi data dan mengembangkan kesimpulan, melakukan refleksi termasuk kategori baik.

Hal ini menunjukkan bahwa pembelajaran yang dilaksanakan telah berjalan sesuai dengan rencana pembelajaran yang telah dikembangkan. Pemberian kesempatan siswa untuk melakukan kegiatan inkuiri seperti merumuskan hipotesis, menentukan variabel, mengumpulkan dan menganalisis data hingga diperoleh kesimpulan dibebankan kepada siswa bukan sebagai tugas individu, melainkan harus didiskusikan dan dicari penyelesaiaannya secara berkelompok. Pemberian tugas siswa secara kelompok pada kegiatan inti memberikan pengalaman bagi siswa untuk terlibat aktif dalam mengkonstruksi sendiri pengetahuannya seperti yang dikemukakan Nur (2008, p. 4) siswa belajar melalui interaksi dengan orang dewasa dan teman sebaya yang lebih mampu. Hal ini juga diperkuat prinsip Vygotsky (Kardi, 2012, p. 28) yang menyatakan bahwa sebagian besar proses belajar manusia adalah akibat dari interaksi antara manusia, baik antara orang dewasa dengan anak-anak ataupun antar sesama anakanak. Pada tahap ini guru juga memberikan bimbingan kepada kelompok siswa yang mengalami kesulitan terkait tugas-tugas kelompok berdasarkan panduan di LKS. Rata-rata skor kegiatan penutup diperoleh sebesar 3,69 dengan kategori baik. Hal ini karena guru memberikan kesempatan kepada siswa untuk terlibat aktif menyimpulkan materi dan bertanya tentang materi yang belum dipahami sebelum pembelajaran diakhiri. Guru juga membiasakan siswa berdoa di akhir pelajaran. Pada tahap ini guru berupaya agar siswa melakukan refleksi terhadap apa yang baru dipelajari siswa.

Aspek pengelolaan waktu pada pertemuan pertama termasuk kategori cukup, tetapi pada pertemuan selanjutnya dapat diatasi dengan memberikan informasi kepada siswa bahwa ketepatan waktu dalam melakukan tugas juga dinilai oleh guru. Aspek suasana kelas diperoleh rata-rata skor sebesar 3,75 dengan kategori baik. Hal ini menunjukkan siswa dan guru antusias dalam pelaksanaan kegiatan pembelajaran.

Secara umum, dapat disimpulkan bahwa guru dapat menerapkan pembelajaran model inkuiri terbimbing dalam membimbing siswa untuk merumuskan hipotesis, memprediksi hasil, mengumpulkan data dan menganalisisnya, melakukan refleksi terhadap pembelajaran yang diterapkan. Dengan demikian, Rencana Pelaksanaan Pembelajaran (RPP) yang dikembangkan pada penelitian ini merupakan perangkat yang termasuk dalam kategori baik sehingga layak digunakan untuk melatihkan keterampilan proses sains siswa.

\section{Aktivitas Siswa}

Aktivitas siswa selama pembelajaran diamati oleh dua orang pengamat. Data persentase aktivitas siswa ditunjukkan pada Gambar 3 berikut ini.

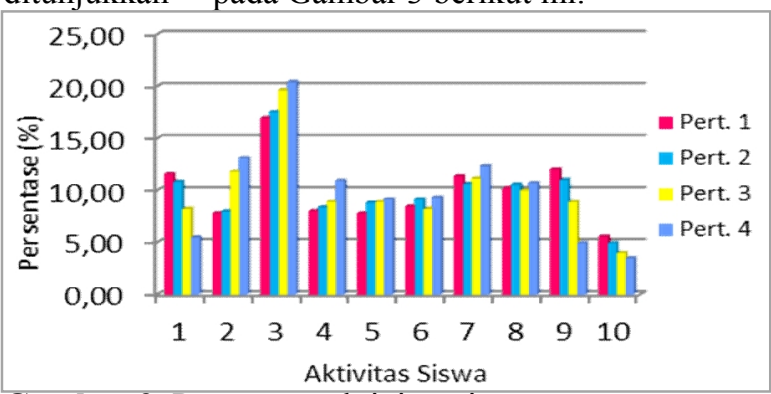

Gambar 3. Persentase aktivitas siswa

Keterangan :

(1) mendengarkan/memperhatikan penjelasan guru,

(2) membaca/mencari informasi LKS/materi ajar, 
(3) melakukan pengamatan saat pengambilan data,

(4) melakukan percobaan sesuai panduan LKS,

(5) mencatat data hasil pengamatan,

(6) mendiskusikan tugas dalam LKS,

(7) menyampaikan pendapat atau bertanya

(8) menjawab pertanyaan guru,

(9) meminta bimbingan guru,

(10) perilaku yang tidak relevan.

Persentase perilaku yang tidak relevan mempunyai rentang 3,49\%-5,58\%, dan aktivitas mendengarkan penjelasan guru mempunyai rentang 5,51\%-11,61\%. Aktivitas lainnya merupakan aktivitas yang berpusat kepada siswa. Hal ini menunjukkan bahwa pembelajaran dengan model inkuiri terbimbing merupakan pembelajaran yang mengedepankan peran aktif siswa, siswa membangun sendiri pengetahuannya, sebagaimana pernyataan Ural (2016, p. 224) bahwa pembelajaran model inkuiri dapat mengembangkan kemampuan berfikir siswa, merumuskan masalah, dan berpartisipasi aktif dalam kegiatan pembelajaran. Hal ini didukung dengan persentase aktivitas siswa tertinggi pada aktivitas melakukan pengamatan saat pengambilan data dengan rentang $16,96 \%-20,42 \%$, hal ini menunjukkan bahwa siswa antusias dan termotivasi untuk mengikuti kegiatan dengan pembelajaran inkuiri terbimbing.

Persentase perilaku siswa yang kurang relevan seperti tidak mau mengerjakan tugas yang sudah dibagikan kelompok masing-masing, membuat gaduh di kelas tanpa aktif dalam pembelajaran mengalami penurunan di setiap pertemuan. Hal ini menunjukkan suasana belajar yang diciptakan dapat menarik siswa sehingga siswa fokus dan berpartisipasi aktif dalam kegiatan pembelajaran seperti hasil penelitian yang dilakukan oleh Ifeoma dan Oge (2013, p. 219) bahwa inkuiri terbimbing berpengaruh terhadap partisipasi aktif siswa dalam kegiatan pembelajaran.

Aktivitas siswa meminta bimbingan kepada guru juga menurun setiap pertemuan. Pada pertemuan pertama siswa lebih banyak meminta bimbingan pada guru karena belum terbiasa dengan model pembelajaran yang diterapkan. Pemberian bimbingan kepada siswa dilakukan dengan menggunakan pertanyaan-pertanyaan yang mengarahkan siswa untuk menemukan jawaban terhadap tugas yang harus diselesaikan secara mandiri.

\section{Keefektifan Perangkat Pembelajaran}

1. Keterampilan Proses Sains

Instrumen keterampilan proses sains dikembangkan berdasarkan indikator keterampilan proses sains untuk mengukur kompetensi keterampilan proses sains siswa seperti pernyataan Harlen \& Elstgeest yang dikutip oleh Sheeba (2013, p. 113) each competency indicator is one of the many behavior examples which may be used to

Pengembangan Perangkat Pembelajaran IPA Model Inkuiri

Terbimbing untuk ... assess student competency in the particular process skill.

Data persentase ketuntasan keterampilan proses sains yang diperoleh dari metode tes ditunjukkan pada Gambar 4 berikut ini

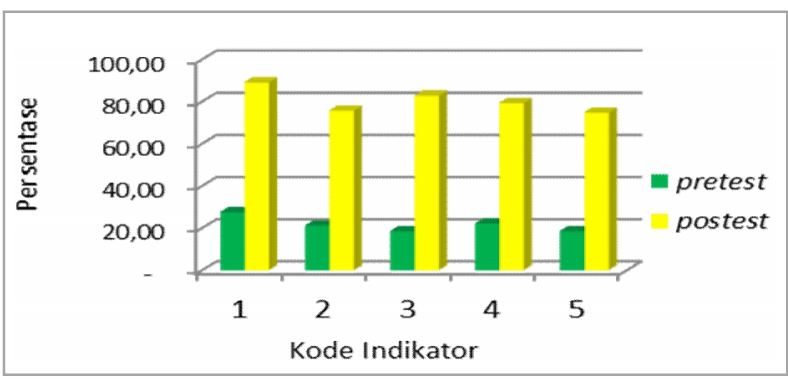

Gambar 4. Ketuntasan klasikal indikator KPS

Keterangan :

$1:$ Memprediksi

2 : Merumuskan hipotesis

3 : Identifikasi variabel

4 : Interpretasi data

5 : Merumuskan kesimpulan

Data pencapaian ketuntasan siswa untuk setiap indikator keterampilan proses sains siswa ditunjukkan Gambar 5 berikut ini.

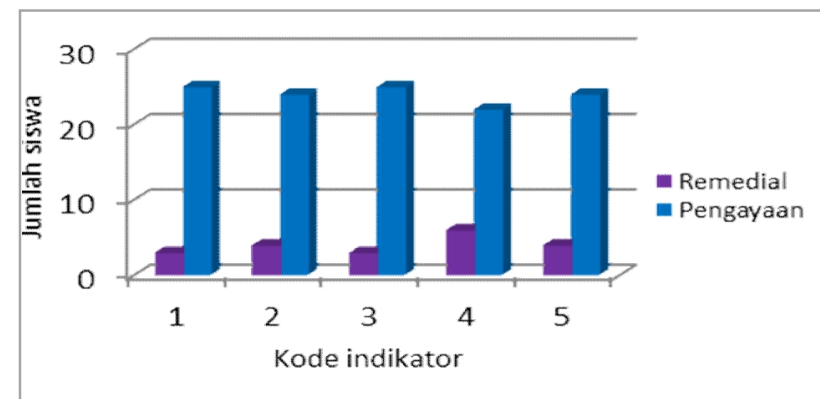

Gambar 5. Jumlah Ketuntasan Indikator Siswa

Keterangan :

1 : Memprediksi

2 : Merumuskan hipotesis

3 : Identifikasi variabel

4 : Interpretasi data

5 : Merumuskan kesimpulan

a) Memprediksi

Persentase ketuntasan terbesar diperoleh pada indikator keterampilan memprediksi. Hal ini disebabkan indikator memprediksi merupakan kompetensi yang paling rendah dari kelima keterampilan yang dilatihkan pada penelitian ini dan termasuk keterampilan proses sains dasar. Di samping itu keterampilan memprediksi sesuai dengan perkembangan siswa pada tahap operasi konkrit sebagaimana pernyataan Sheeba (2013, p.111) basic science process skill apply specifically to foundational cognitive functioning especially in the elementary grades, sedangkan 28 siswa kelas VIII berusia dengan rentang 12-13 tahun berada pada tahap operasi formal sebagaimana tahap perkembangan yang dikemukakan Piaget. Berarti, keterampilan memprediksi sebenarnya 
sudah berkembang bagi siswa yang ditunjukkan persentase keterampilan memprediksi pretest terbesar yaitu $27,68 \%$, namun belum mencapai ketuntasan, kemudian diterapkan pembelajaran inkuiri terbimbing persentase ketuntasan naik menjadi 89,29\%.

Faktor lainnya yaitu guru menghadirkan fenomena pada setiap awal pembelajaran yang bertujuan untuk memotivasi siswa dan melatih siswa keterampilan memprediksi pada awal pembelajaran. Fenomena tersebut harus diamati oleh siswa, kemudian siswa memprediksi terhadap peristiwa selanjutnya berkaitan dengan fenomena tersebut. Siswa ke-3, siswa ke-6, dan siswa ke-21 merupakan siswa yang tidak mencapai ketuntasan indikator memprediksi, hal ini disebabkan pada kegiatan awal pembelajaran siswa kurang memperhatikan fenomena yang dihadirkan oleh guru. Solusi yang memungkinkan untuk diterapkan untuk mengatasi siswa yang belum mencapai ketuntasan indikator memprediksi yaitu pemberian latihan atau remedial.

\section{b) Merumuskan hipotesis}

Hasil persentase ketuntasan keterampilan merumuskan hipotesis sebesar $75,89 \%$. Merumuskan hipotesis merupakan keterampilan berfikir tingkat tinggi sebagaimana kategori keterampilan berfikir yang diajukan oleh McGregor (dalam Ozgelen, 2012, p. 286) bahwa merumuskan hipotesis berkaitan dengan keterampilan berfikir mencipta (creativity). Mencipta merupakan dimensi proses kognitif yang tertinggi berdasarkan taksonomi Bloom setelah mengevalusi (Arends, 2012, p. 115). Merumuskan hipotesis dalam kerangka dimensi proses kognitif juga termasuk kategori create (Anderson and Krathwol, 2001, p.31). Empat siswa tidak mencapai ketuntasan indikator merumuskan hipotesis yaitu Siswa ke-4, Siswa ke-19, siswa ke-26, Siswa ke-27. Salah satu solusi yang diharapkan dapat mengembangkan keterampilan merumuskan hipotesis yaitu remedial bagi siswa atau pemberian latihan yang berkaitan dengan indikator keterampilan merumuskan hipotesis.

c) Identifikasi Variabel

Hasil persentase identifikasi variabel diperoleh $83,04 \%$. Tingginya pencapaian ini dikarenakan siswa dapat menentukan variabel yang diuji berkaitan dengan fenomena yang diberikan sesuai dengan kriteria yang ditentukan. Penyebab lainnya yaitu guru memberikan bimbingan yang luas kepada siswa dengan mengajukan pertanyaan-pertanyaan yang mengarahkan siswa pada inkuiri pada tahap awal pembelajaran kemudian secara bertahap guru mengurangi bimbingan sebagaimana pernyataan Nur (2008, p. 14) pemberian kepada siswa bantuan yang lebih terstruktur pada awal pelajaran dan secara bertahap mengalihkan tanggung jawab belajar kepada siswa untuk bekerja atas arahan diri mereka sendiri. Faktor lainnya pembelajaran ditunjang dengan buku ajar siswa yang memuat arahan dan deskripsi secara rinci tentang identifikasi variabel percobaan. Siswa ke-8, siswa ke 20, dan siswa ke-23 tidak mencapai ketuntasan indikator identifikasi variabel, namun jumlahnya relatif kecil jika dibandingkan dengan indikator keterampilan proses lainnya. Solusi yang diberikan yaitu remedial terkait indikator identifikasi variabel.

d) Interpretasi data

Persentase ketuntasan interpretasi data yaitu $79,46 \%$. Pencapaian ini relatif tinggi jika dibandingkan dengan indikator merumuskan hipotesis dan merumuskan kesimpulan. Penyebab tingginya pencapaian tersebut dikarenakan siswa sudah mulai terlatih untuk memprediksi, membuat penyajian data yang disertakan dalam laporan praktikum dalam setiap pertemuan, karena melatihkan keterampilan proses ini, dibutuhkan keterampilan proses lainnya seperti membuat prediksi, inferensi, dan merumuskan hipotesis seperti yang dikemukakan oleh Ozgelen (2012, p. 284) interpreting data involves others SPS, such as making predictions, inferences, and hypotheses from collected data.

Meskipun ketuntasan indikator interpretasi data secara klasikal tinggi, tetapi indikator interpretasi data siswa termasuk rendah. Pada indikator interpretasi data, 6 siswa (Siswa ke-1, siswa ke-10, siswa ke-13, siswa ke-16, siswa ke-19, dan siswa ke-22) tidak mencapai ketuntasan yang merupakan jumlah ketidaktuntasan terbesar dari indikator lainnya. Hal ini disebabkan karena pada pertemuan ke-1 saja siswa dilatihkan untuk menggambarkan grafik hubungan antara variabel manipulasi dan variabel respon. Solusi yang ditawarkan untuk mengembangkan keterampilan ini yaitu remedial atau latihan pengembangan keterampilan dalam interpretasi data yang tercantum dalam LKS atau buku ajar siswa.

e) Merumuskan kesimpulan

Persentase ketuntasan indikator merumuskan kesimpulan mencapai batas minimal yaitu $75,00 \%$. Hal ini disebabkan indikator merumuskan kesimpulan termasuk juga keterampilan proses level tinggi seperti pernyataan Aydin (2013, p. 58) yang menyatakan bahwa drawing conclusion is a higher-level process skill. Meskipun pencapaian ini merupakan ketuntasan indikator terendah secara klasikal, tetapi sudah mencapai ketuntasan minimal. Pencapaian ini dikarenakan pada akhir pembelajaran siswa dilibatkan dalam merumuskan kesimpulan bersama guru pada kegiatan penutup dan umpan balik diberikan terkait laporan penyusunan laporan percobaan yang dikumpulkan setiap akhir pertemuan. Empat siswa (siswa ke-7, siswa ke-10, siswa ke-13, siswa ke-16) tidak mencapai ketuntasan indikator merumuskan kesimpulan. Solusi yang memungkinkan untuk 
diberikan untuk mencapai ketuntasan tujuan pembelajaran terkait indikator merumuskan kesimpulan yaitu remedial dan pemberian latihan secara intensif.

Secara keseluruhan, pembelajaran inkuiri terbimbing dapat meningkatkan keterampilan proses sains. Hal ini sesuai dengan pendapat Joyce dan Weil (2002, p. 185) yang menyatakan bahwa model pembelajaran inkuiri terbimbing ini mengembangkan strategi inkuiri yang meliputi keterampilan proses yang meliputi pengamatan, mengumpulkan dan mengorganisasi data, mengidentifikasi dan mengontrol variabel, menguji dan merumuskan hipotesis, keterampilan menjelaskan dan inferensi.

Pengkategorian kemampuan keterampilan proses sains siswa juga terjadi peningkatan. Hasil kategori kemampuan keterampilan proses sains siswa sebelum diterapkan pembelajaran model inkuiri terbimbing 28 $(100 \%)$ siswa termasuk berkemampuan rendah. Setelah pembelajaran diterapkan, kategori kemampuan siswa menjadi meningkat yaitu $9(33 \%)$ siswa mempunyai kemampuan keterampilan proses sains sedang dan 19 (67\%) siswa termasuk kategori tinggi. Data keterampilan proses sains yang diperoleh dari penilaian kinerja ditunjukkan pada Gambar 6 berikut ini.

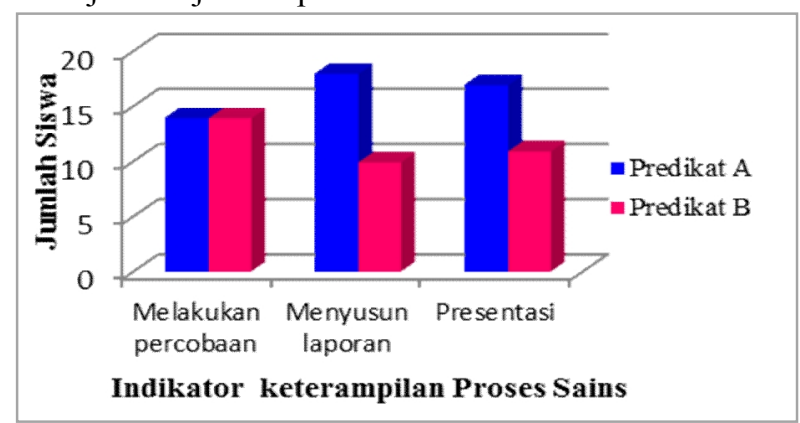

Gambar 6. Unjuk Kerja Keterampilan Proses Sains

Persentase ketuntasan siswa pada aspek keterampilan melakukan percobaan mencapai $100 \%$. 14 siswa memperoleh nilai 77,78 dengan kategori baik dan 14 siswa lainnya memperoleh kategori sangat baik. Hal ini disebabkan karena pada awal-awal pembelajaran guru sering mengingatkan dan menyampaikan bahwa ketepatan waktu dan kemandirian siswa dalam kegiatan melakukan percobaan di kelas termasuk penilaian. Hal ini mendorong siswa termotivasi untuk menyelesaikan tugas lebih cepat, siswa juga bersemangat membaca buku ajar siswa sebelum pembelajaran.

Persentase ketuntasan siswa pada aspek keterampilan menyusun laporan mencapai $100 \%$. Seluruh siswa sudah mencapai kriteria ketuntasan yang ditetapkan yaitu 73 yang ditetapkan sekolah. 10 siswa memperoleh nilai menyusun laporan sebesar 83,33 sedangkan nilai keterampilan menyusun laporan sebesar 88,89 diperoleh 18 siswa. Hal ini disebabkan karena sebagian unsur penilaian keterampilan menyajikan laporan merupakan aspek keterampilan proses sains yang dilatihkan yang tercantum di LKS, guru sering memberikan bimbingan yang lebih pada awal-awal pertemuan, di samping itu petunjuk penyusunan laporan diberikan kepada siswa untuk memudahkan siswa dalam menyusun laporan percobaan.

Pertemuan pertama keterampilan presentasi siswa memperoleh nilai yang rendah, hal ini dikarenakan siswa belum terbiasa mempresentasikan hasil percobaan di kelas, siswa terlihat kaku dalam menyajikan laporan percobaannya, namun pada pertemuan berikutnya siswa sudah mulai menunjukkan keberaniannya menyampaikan pendapat dan menyajikan laporannya.

Hasil analisis data menunjukkan bahwa persentase ketuntasan siswa pada aspek keterampilan presentasi mencapai $100 \%$. Seluruh siswa sudah mencapai kriteria ketuntasan yang ditetapkan yaitu 73 yang ditetapkan sekolah. 12 siswa memperoleh nilai keterampilan presentasi sebesar 77,78 , dan nilai sebesar 88,89 diperoleh 16 siswa.

Dapat disimpulkan bahwa pembelajaran inkuiri terbimbing yang diterapkan dapat meningkatkan aspek keterampilan menyusun laporan siswa, hal ini sesuai dengan pernyataan yang dikemukakan oleh Bilgin (2009, p. 1039) guided inquiry activities help students to develop their individual responsibility, cognitive methods, report making, problem solving, and understanding skills.

Dengan demikian pembelajaran model inkuiri terbimbing efektif untuk melatihkan keterampilan proses sains siswa. Hasil yang sama ditunjukkan oleh penelitian yang dilakukan oleh Rizal $(2014,163)$ dan Nworgu \& Otum (2013, p. 39) bahwa inkuiri terbimbing berpengaruh terhadap keterampilan proses sains siswa.

\section{KESIMPULAN}

\section{A. Simpulan}

Berdasarkan uraian di atas, dapat dirumuskan perangkat pembelajaran model inkuiri terbimbing yang dikembangkan dinyatakan layak (valid, praktis, dan efektif) untuk melatihkan keterampilan proses sains siswa SMP pada materi getaran, gelombang, dan bunyi.

\section{B. Saran}

1. Pengembangan perangkat pembelajaran model inkuiri terbimbing dapat melatihkan keterampilan proses sains siswa sehingga perlu dikembangkan secara lebih luas pada materi pembelajaran IPA lainnya.

2. Pengembangan perangkat pembelajaran model inkuiri terbimbing dapat dilengkapi dengan RPP untuk kegiatan remedial dan pengayaan yang 
bertujuan untuk tindakan lanjutan bagi siswa yang belum mencapai ketuntasan dan sudah mencapai ketuntasan indikator komponen keterampilan proses sains.

\section{REFERENSI}

Anderson, L.W. and Krathwol, D. R (2001). A Taxonomy for Learning, Teaching and Assesing. United States :Addison Wesley Longman.

Arifin, Z. (2010a). Evaluasi Pembelajaran Prinsip Teknik dan Prosedur. Bandung: Remaja Rosdakarya.

Arends, R. I. (2012). Learning to Teach. New York:McGraw-Hill.

Aydin, A. (2013). Representation of Science Process Skill in the Chemistry Curricula for Grade 10, 11, and 12/Turkey. International Journal of Education and Practice. 1 (5) :51-63 http://www.pakinsight.com/journals/IJEP.htm

Aydogdu, B., Erkol, M., \& Erten N. (2014). The Investigation of science Process Skill of Elementary School Teachers in terms of Some Variables: Perspective from Turkey.Asia Pacific Forum on Science Learning and Teaching.15(1). $1-4$.

Bilgin, I. (2009). The Effects Of Guided Inquiry Instruction Incorporating A Cooperative Learning Approach on University Students'achievement of Acid and Bases Concepts and Attitude Toward Guided Inquiry Instruction. Scientific Research and Essay. Vol. 4 (10), pp 1038-1046.

Duran, M. (2014). A study on $7^{\text {th }}$ grade students' inquiry and communication competencies. Procedia - Social and Behavioral Sciences. 116 (2014).4511-4516. Ifeoma \& Oge.(2013). Effects of Guided Inquiry Method on Secondary School Students' Performance in Social Studies Curriculum in Anambra State, Nigeria. British Journal of Education, Society \& Behavioural Science. 3(3).206-222. Joyce, B and Weil, M. (2002). Model of Teaching. USA: Allyn and Bacon Publishing Company.

Kardi, S. (2012). Pengantar Pengembangan Kurikulum dan Rencana Pelaksanaan Pembelajaran. Modul tidak dipublikasikan. Unesa.

Kemendikbud. (2014). Lampiran III Permendikbud. PP No. 58 Tahun 2014 Tentang Kurikulum 2013 Sekolah Menengah Pertama/Madrasah Tsanawiyah. Jakarta: Kementerian Pendidikan dan Kebudayaan.

Kemendikbud. (2015). Lampiran Permendikbud Nomor 53 tentang Penilaian Hasil Belajar Oleh Pendidik dan Satuan Pendidikan pada
Pendidikan Dasar dan Pendidikan Menengah. Jakarta: Dirjen Pendidikan Dasar dan Menengah.

Kuhlthau, C. C., Maniotes, L.K, \& Caspari A.K. (2007). Guided Inquiry Learning in the $21^{\text {st }}$ Century. London: British Libraries.

Nur, M. (2008). Pengajaran Berpusat kepada Siswa dan Pendekatan Kontruktivis dalam Pengajaran. Surabaya: Pusat Sains dan Matematika Sekolah.

Nworgu dan Otum. (2013). Effect of Guided Inquiry with Analogy Instructional Strategy on Students Acquisition of Science Process Skills. Journal of Education and Practice. 27(4). 35-40.

Ozgelen, S. (2012). Students Science Process Skills within a Cognitive Domain Framework. Eurasia Journal of Mathematics, Science \& Technology Education. 8 (4) : 283-292.

Padilla, M. J, (1990). The Science Process Skills.Research matters to the Science Teacher, No. 9004. Reston, VA: National Association for

Ratumanan, T.G dan Laurens T. (2011). Penilaian Hasil Belajar pada Tingkat Satuan Pendidikan. Surabaya:Universitas Negeri Surabaya Press.

Riduwan. (2012). Skala Pengukuran Variabel-Variabel Penelitian. Bandung: Alfabeta.

Rizal, M. (2014). Pengaruh Pembelajaran Inkuiri Terbimbing dengan Multi Representasi terhadap Keterampilan Proses Sains dan Penguasaan Konsep IPA SMP. Jurnal Pendidikan Sains. 2 (3). 159-165.

Sheeba, M.N. (2013). An Anatomy of Science Process Skills In The Light of The Challenges to Realize Science Instruction Leading To Global Excellence in Education. Educationia Confab. 2 (4) :108-123

Sukarno, Permanasari, A., \& Hamidah, I. (2013). The Profile of Science Process Skill (SPS) Student at Junior High School. International Journal of Scientific Engineering and Research. 1(1). 23473878.

Ural, E. (2016).The Effect of Guided-Inquiry Laboratory Experiments on Science Education Student's Chemistry Laboratory Attitudes, Anxiety and Achievement. Journal of Education and Training Students. 4(4) 217-227.

Wasis. (2015). Hasil Pembelajaran Sains di Indonesia: Problem dan Upaya Mengatasinya. Semnas 2015 "Pembelajaran dan Penilaian Sains Sesuai Tuntutan Kurikulum 2013”. PPS Unesa 